\title{
Space Inside, Space Outside: the Non-Locality of Mind
}

\author{
Ajahn Amaro ${ }^{1}$ \\ Accepted: 14 October 2020 / Published online: 26 October 2020 \\ (C) Amaravati Publications 2020
}

At the beginning of the day, in the cool of the early morning, as light and color are beginning to come back into the world, bring attention to the quality of inner space, the space in this room and the space in the world around us. Developing that attention, we notice the space that's always here, the space around things, the space within things. This helps us to recollect, to awaken to the inner space, the space of our minds which receives and contains, which encompasses all thoughts, feelings, perceptions, moods.

Bring attention to the inner sound. The sound of silence directly supports the attending, the awakening to the quality of inner space. Awakening to the sound of silence helps remind us that the quality of the heart's awareness is infinitely accommodating. It has room for everything. Allow the heart to rest in that quality of open awareness, spacious awareness, receiving the experience of sound, sensations in the body, feelings of warmth or coolness, light or dark. Allow the heart to be that receptive, spacious, accommodating awareness, receiving all things without bias, without partiality. The heart is an infinite open space which accommodates all things, rejects nothing, allows everything in and holds on to nothing. Space does not hold the objects in it. In the same way, the space of our minds receives all things, lets go of all things. Sound arises and passes, our moods arise and pass, a feeling arises and passes - there is nowhere for them to land, nothing for them to stick to. Let the moods and feelings be known as they take shape and do their thing, and then as they dissolve, leaving no remainder.

We talk about letting go, we use that kind of language, but notice how it also implies that there has been a holding on, a "me" who has been doing some holding. But more truly, in a more real and complete way, it is not so much a matter of

Excerpted from The Breakthrough by Ajahn Amaro, Amaravati Publications, 2016

Ajahn Amaro

ajahn.amaro@gmail.com

1 Amaravati Buddhist Monastery, Hemel Hempstead, Hertfordshire HP1 3BZ, UK letting go but of training the heart not to grasp, not to identify, not to create that illusion of ownership in the first place.

A sound arises and passes with no remainder. A word is spoken - we hear it, it arrives, it is known, it is gone. There is silence before the word and silence after it. There does not need to be any kind of remainder. We do not need to let go of a sound. A sound comes and goes on its own. We know we cannot own it, hold it or keep it. So rather than letting go, recognize the truthnothing is ever really owned or possessed by an "I" or a "me". The practice is sustaining that awareness of the inexorable, incessant flow - the change, the modulation of perceptions, patterns of consciousness, patterns of nature, arising, blossoming, dissolving, following their own laws.

A star a cloud or a sunset cannot be possessed, but it can be known. In the same way, just allow the feelings of the bodyemotions, moods, thoughts - to be ownerless, to arise, take shape, be fully received and known, and then let them dissolve. Be that unlocated, non-possessive heart of awareness. Be that quality of knowing which participates in all experience, but without confusion, without possessiveness. Develop this so that the layers of attachment and identification, the layers of self-view, are seen more and more clearly, and let go of.

In the Udāna, the Inspired Utterances, the Buddha says there is that sphere of being, that ayyatana, where there is no earth, no water, no fire, no wind, where there is neither this world nor another world, there is no infinite consciousness, infinite space or nothingness. And in that realm of being, that ayyatana, there is no moon, no sun, no stars. There is neither a coming nor a going, nor a standing still. There is no basis, there is no development, no support. This, just this, is the end of dukkha.

When we hear those words they can make us feel insecure and threatened. No sun? No moon? No stars? No development? No support? What is that! You can feel a kind of spiritual vertigo, being suddenly knocked off balance. But all that is happening here is an unplugging, a dissolving of our familiar patterns of identification and clinging - our clinging to a "me" who is here in this place, experiencing this world which seems to exist around me in three-dimensional space. So these words from the Buddha are threatening to the ego, to the 
habits of identification with time and three-dimensional experience, but to the heart itself, they are greatly liberating, freeing. In that ayatana, that realm of being, there is neither a coming nor a going nor a standing still. "Place" does not apply. "Here" and "there" do not apply. Past and future do not apply.

Luang Por Chah used to expound on this teaching by asking, "If you can't go forwards and you can't go back and you can't stay still, where do you go?' It's a conundrum, a puzzle that confuses the thinking, rational mind. There is no solution when we are identified with the body, with time and space, the sense world. If you tried to give Ajahn Chah a clever answer and say that you could go sideways or up a tree, he would tell you, "No, can't go sideways, or up or down either. Where do you go?" The only way to solve the conundrum is to let go of identification with the body, with time and place. If there are clinging and identification with the body, with threedimensional space, the conundrum is insoluble; there is no answer, no solution. But if we really take to heart this daily reflection that the body is not self, feelings are not self, perceptions are not self, that is not who or what we are . .

If there is non-identification with physical form, with the sense world, with perceptions, then there is awareness - nonidentification is that unentangled participating in experience. This participation is not tied to a personality, an individuality, a physical spot; this awareness, this knowing, is unlocated.

You might be thinking, "But I can feel a pain in my knee, I can feel a tickle in my throat; when I cough that cough is happening in my throat, and my throat is right here underneath my mouth, above my chest - that's where it is". But the mind is constructing space. The mind creates an image of the body as a pattern of consciousness, and it orients the different parts of the body according to the pattern that it has created. When you look and explore, where is your throat? Where is the knee? You see how the mind has created an internal map. The mind says, "My knee is down here to the left. My throat is here in the middle where the cough is happening". To common sense it says, "Well, it's right here, obviously". But with the uncommon sense of wisdom, we pick that up, explore it, and begin to see that "here" and "there" are constructs woven together by our habits and faculties of the mind.

During the day we sit in meditation, we walk in meditation, we go about our business, eat our breakfast, brush our teeth, pull up weeds in the garden. As these daily patterns and events unfold, we can investigate these themes. On one level it seems like "I am walking forward" or "I am sitting here". But see what happens, see how it changes when we shift the attitude and recognize that there is the perception of the body walking, there is the perception of the hands moving; but that which knows the movement is not moving. See if you can discern that quality, that mysterious, beautiful openness of awareness which is free from moving forwards, moving backwards, free from standing still in this spot.

In the last message that Luang Por Chah sent Ajahn Sumedho, the letter Luang Por sent just before he had his stroke and lost his ability to move and speak and teach, he said: "Whenever you have feelings of love and hate for anything whatsoever, these will be your partners in building pāramī, spiritual virtues. The BuddhaDhamma is not to be found in moving forwards, nor in moving backwards, nor in standing still. This, Sumedho, is your place of non-abiding". This was Luang Por Chah's final instruction to his disciple who was setting up monasteries in the West. It wasn't a list of "do this and don't do that". It wasn't an exhortation to always remember to follow the traditions. He just reminded him of this one central, crucial principle: non-abiding, non-clinging. When the heart attunes itself to the Dhamma in this radical and complete way, it is able to respond to every situation. When we need to be conservative, we can be conservative. When we need to be creative, we can be creative. When we need to hold steady, we hold steady. When we need to adapt, we adapt. Through that nonclinging there is a supreme attunement to time, place, situation, to what each moment demands.

So that was the most appropriate and best advice to Ajahn Sumedho as he was starting up these new monasteries in the West - to let go of progress, to let go of degeneration, even to let go of holding steady. The Buddha-Dhamma is not to be found in moving forwards, nor in moving backwards, nor in standing still. It is here in the place of non-abiding, non-identification, no-thing-ness. It is here in the place of complete openness and receptivity.

Publisher's Note Springer Nature remains neutral with regard to jurisdictional claims in published maps and institutional affiliations. 